$\begin{array}{rr}\text { JURNAL } & \text { Volume } 17, \text { Nomor } 1, \text { Januari } 2021 \\ \text { FIT(1)PATOLOGI } & \text { Halaman } 9-18 \\ \text { I N D ON E I A } & \text { DOI: } 10.14692 / \text { ji. } 17.1 .9-18 \\ \text { ISSN: } 0215-7950 & \end{array}$

\title{
Metode single image-NDVI untuk deteksi dini gejala mosaik pada Capsicum annuum
}

\section{Single image-NDVI method for early detection of mosaic symptoms in Capsicum annuum}

\author{
Asmar Hasan ${ }^{1,2}$, Widodo', Kikin Hamzah Mutaqin', \\ Muhammad Taufik ${ }^{2}$, Sri Hendrastuti Hidayat ${ }^{1 *}$ \\ ${ }^{1}$ Departemen Proteksi Tanaman, Fakultas Pertanian, IPB University, 16680 \\ ${ }^{2}$ Jurusan Proteksi Tanaman, Fakultas Pertanian, Universitas Halu Oleo, 93231
}

\begin{abstract}
ABSTRAK
Mosaik adalah gejala penyakit yang sering ditemukan pada tanaman cabai merah (Capsicum annuum) dan umumnya disebabkan oleh infeksi virus seperti Tobacco mosaic virus. Infeksi yang berat bahkan dapat mengakibatkan tanaman menjadi kerdil dan mengalami kehilangan hasil yang nyata. Metode serologi dan molekuler sudah banyak digunakan untuk mendeteksi virus tetapi pengerjaannya cukup menyita waktu, relatif kurang efisien untuk sampel yang banyak, dan bersifat destruktif pada tanaman. Di sisi lain, pengamatan gejala secara langsung terkendala oleh kemampuan visual manusia dan gejala laten pada tahap awal infeksi. Oleh karena itu, metode deteksi berdasarkan kemampuan tanaman menyerap dan merefleksikan berbagai spektrum cahaya matahari, seperti normalized difference vegetation index (NDVI) berpotensi untuk dikembangkan. Penelitian ini bertujuan untuk mengevaluasi potensi single image-NDVI sebagai varian NDVI untuk pengembangan deteksi dini gejala mosaik pada cabai merah. Tahapan utama penelitian ialah perekaman citra tanaman cabai merah yang tidak diinokulasi virus (V0), diinokulasi (V1), dan minim hara (M) menggunakan kamera RGB tanpa modifikasi dan filter lensa untuk menangkap reflektansi cahaya biru dan Near-Infrared. Selanjutnya dilakukan pengolahan citra menggunakan plugin Photo Monitoring pada aplikasi Fiji-ImageJ. Perekaman dilakukan mulai 1 hari setelah inokulasi (HSI) sampai gejala terlihat kasat mata. Hasil penelitian menunjukkan bahwa terjadi tendensi peningkatan nilai NDVI terintegrasi pada semua perlakuan. Namun, tendensi peningkatan pada V1 tidak nyata dibandingkan dengan V0 dan M. Selisih rata-rata nilai NDVI terintegrasi antara V1 terlihat sangat nyata dibandingkan dengan V0 (pada 5 HSI) dan M (pada 1 HSI). Tingkat sensitivitas, spesifisitas, dan akurasi metode ini berkisar antara $80-90 \%$ pada 5 HSI.
\end{abstract}

Kata kunci: akurasi, Fiji-ImageJ, normalized difference vegetation index, sensitivitas, spesifisitas

\section{ABSTRACT}

Mosaics are a symptom of a disease often found in red chilies (Capsicum annuum) and is generally caused by viral infections such as the Tobacco mosaic virus. Severe infection can cause stunting and significant yield loss. Serological and molecular detection is a common detection method for plant viruses although they are time-consuming, relatively inefficient for large samples, and are destructive to plants. On the other hand, direct symptoms observation is hampered by human visual abilities and

*Alamat penulis korespondensi: Departemen Proteksi Tanaman, Fakultas Pertanian, IPB University. Jalan Kamper, Kampus IPB Darmaga, Bogor 16680.

Tel: 0251-8629364, Faks: 0251-8629362, Surel: srihendrastuti@apps.ipb.ac.id 
latent symptoms in virus infection. Therefore, detection method based on the plant's ability to absorb and reflect various spectrums of sunlight, such as the normalized difference vegetation index (NDVI), has the potential to be developed. This study aims to evaluate the potential of a single image-NDVI as an NDVI variant for the early detection of mosaic symptoms in red chilies. The main activity involved image recording of chili plants that were not inoculated (V0) and inoculated (V1) by the virus, and given minimal nutrients (M) using an unmodified RGB camera and lens filter to capture blue and NearInfrared light reflection. Furthermore, image processing is carried out using the Photo Monitoring plugin on the Fiji-ImageJ application. The recording was done one day after inoculation (dai) until the symptoms were visible. The results showed that there was an increasing trend in the integrated NDVI value in all treatments. Howewer, the increasing trend in V1 was not significant compared to V0 and $M$. The difference in the mean value of integrated NDVI between V1 was very significant compared to $\mathrm{V} 0$ (at 5 dai) and M (at 1 dai). This method's level of sensitivity, specificity, and accuracy ranges from $80-90 \%$ at 5 dai.

Keywords: accuracy, Fiji-ImageJ, normalized difference vegetation index, sensitivity, specificity

\section{PENDAHULUAN}

Mosaik adalah gejala penyakit tanaman yang umum disebabkan oleh infeksi virus termasuk diantaranya ialah Tobacco mosaic virus (TMV). Infeksi TMV telah dilaporkan pada berbagai jenis tanaman budi daya, termasuk pada tanaman cabai merah (Capsicum annuum). Pada infeksi TMV yang berat tidak hanya menimbulkan gejala mosaik, tetapi juga dapat menyebabkan tanaman menjadi kerdil dan mengalami kehilangan hasil yang nyata (Pazarlar et al. 2013; Damiri et al. 2017).

Gejala mosaik yang disebabkan oleh infeksi virus dapat dengan mudah dikenali di lapangan. Namun sering terjadi infeksi virus tidak kasat mata karena adanya gejala laten pada tahap awal infeksi virus atau kondisi lingkungan tertentu. Secara visual, gejala awal infeksi laten terlihat sama seperti tanaman sehat.

Sampai saat ini pendekatan metode serologi dan molekuler masih menjadi pilihan utama untuk melakukan deteksi virus karena kedua metode tersebut memiliki sensitivitas dan spesifitas yang tinggi (Kumar et al. 2011; Kumar dan Prakash 2016; Almeida et al. 2018). Walaupun demikian, kedua metode tersebut memerlukan waktu yang relatif lama, kurang efisien untuk jumlah sampel yang banyak, dan memerlukan tindakan destruktif pada tanaman.

Gejala mosaik timbul akibat perubahan struktur seluler tanaman, seperti terdegradasinya kandungan klorofil daun yang berdampak terhadap perubahan karakteristik reflektansi spektral daun tanaman (Jacquemoud dan Ustin 2001). Beberapa ahli telah mencoba mengembangkan metode deteksi kesehatan tanaman berdasarkan kemampuan tanaman dalam menyerap dan merefleksikan berbagai spektrum cahaya yang dipancarkan oleh sinar matahari (Sankaran et al. 2013; Calderón et al. 2015; Mahlein 2016; Kshirsagar et al. 2019; Miranda et al. 2020). Hasil penelitian menunjukkan bahwa tanaman tembakau (Nicotiana tabacum) yang terinfeksi Cucumber mosaic virus (CMV), Tomato spotted wilt virus (TSWV), Tomato mosaic virus (ToMV), dan Potato virus $Y$ (PVY) memiliki reflektansi spektrum NIR dan cahaya tampak yang berbeda dengan tanaman sehat, serta secara statistik berbeda nyata pada kisaran panjang gelombang 640-680 nm (Krezhova et al. 2009). Oleh karena itu, gejala yang muncul akibat infeksi virus pada tanaman dapat dinilai berdasarkan pengukuran reflektansi spektral daun tanaman, misalnya dengan metode normalized difference vegetation index (NDVI) (Bosse et al. 2019; Oh et al. 2019; Vanella et al. 2020)

Saat ini berbagai macam indeks vegetasi telah menjadi standar penilaian kesehatan tanaman, termasuk metode NDVI (Beisel et al. 2018). NDVI dapat dihitung menggunakan panjang gelombang spektrum elektromagnetik cahaya merah (red radiance) yang berkisar 0.63-0.69 $\mu \mathrm{m}$ dan inframerah-dekat (NIR) 
yang berkisar $0.75-0.80 \mu \mathrm{m}$. NDVI tersebut berkaitan dengan kandungan klorofil dan kemampuannya menyerap cahaya yang men-cerminkan proses fotosintesis tanaman (Tucker 1979; Tattaris et al. 2016). Metode NDVI dengan cahaya merah dan NIR sudah banyak digunakan untuk mendeteksi tanaman sakit (Chávez et al. 2009; Lowe et al. 2017; Hornero et al. 2018). Beisel et al. (2018) melaporkan penggunaan metode single imageNDVI (SI-NDVI) untuk mendeteksi cekaman abiotik pada tanaman dengan memanfaatkan reflektansi cahaya biru dan NIR menggunakan alat bantu kamera RGB yang dimodifikasi dan diberi filter lensa khusus.

Keunggulan metode SI-NDVI ialah bersifat non-desktruktif, relatif murah dan mudah aplikasikan. Metode ini sangat potensial untuk dikembangkan sebagai metode deteksi dini infeksi virus, khususnya untuk perkembangan infeksi laten virus yang sukar diamati secara kasat mata.

Penelitianinibertujuanuntuk mengevaluasi potensi SI-NDVI sebagai metode deteksi dini gejala mosaik pada tanaman cabai merah menggunakan kamera RGB tanpa modifikasi dan filter lensa khusus yang dapat menangkap reflektansi cahaya biru dan NIR secara bersamaan.

\section{BAHAN DAN METODE}

\section{Persiapan Tanaman dan Inokulasi Virus}

Percobaan dilakukan pada bulan Desember 2019 sampai Februari 2020 di lahan penelitian di Kabupaten Bogor, Provinsi Jawa Barat. Persiapan tanaman diawali dengan menyemai benih cabai merah kultivar Matador pada baki semai yang diberi alas tisu lembap selama \pm 1 minggu. Setelah berkecambah benih dipindah tanam ke dalam 10 pot plastik untuk setiap perlakuan, yaitu perlakuan tanpa inokulasi virus (V0), inokulasi virus (V1), dan minim hara $(\mathrm{M})$. Medium tanam campuran pupuk kandang sapi, tanah, dan arang sekam $(1: 1: 1 \mathrm{v} / \mathrm{v})$ digunakan untuk perlakuan cukup hara (V0 dan V1), sedangkan medium tanam campuran zeolite dan arang sekam (1:1 v/v) digunakan pada perlakuan minim hara $(\mathrm{M})$.
Tanaman dipelihara hingga menghasilkan 2 pasang daun terbuka sempurna dan siap diinokulasi. Sebelum dan sesudah inokulasi virus, semua tanaman cabai berada dalam kurungan kedap serangga yang diletakkan di luar ruangan dan terkena sinar matahari langsung. Inokulum virus TMV berasal dari koleksi Laboratorium Virologi Tumbuhan, Departemen Proteksi Tanaman, IPB, yang telah diperbanyak pada tanaman tembakau (Nicotiana tabacum). Inokulasi virus ke tanaman cabai dilakukan secara mekanis (Dijkstra dan Jager 1998).

Serodiagnosis dilakukan pada akhir pengamatan, yaitu pada 29 hari setelah inokulasi (HSI) untuk mengonfirmasi infeksi virus pada tanaman yang diinokulasi. Deteksi virus menggunakan antibodi spesifik TMV dilakukan mengikuti protokol double antibody sandwhich enzyme linked-immunosorbent assay (DAS-ELISA) (DSMZ, Jerman).

\section{Spesifikasi dan Pengaturan Kamera}

Citra SI-NDVI tanaman perlakuan direkam menggunakan kamera RGB merek Canon 750D dengan lensa kit tipe EF-S 18$55 \mathrm{~mm}$ dan On-Lens Filter IR-Ultra Blue. Perekaman secara konsisten dilakukan dengan mode Aperture-Priority (bukaan diafragma = 16.0), kecepatan rana $=$ auto, kecepatan ISO = auto, dan lampu kilat diaktifkan dengan white balance yang disesuaikan. Panjang fokal maksimal lensa yang digunakan ialah $36 \mathrm{~mm}$ dan dengan mode manual fokus. On-Lens Filter IR-Ultra Blue (www. spencercamera.com) digunakan sebagai filter lensa yang memungkinkan kamera menangkap spektrum cahaya dalam kisaran 300-450 nm dan 700-1100 nm yang dipantulkan oleh daun tanaman (Gambar 1).

\section{Perekaman Citra}

Perekaman citra tanaman dilakukan setiap pagi hari setelah inokulasi virus (kecuali kondisi hujan). Perekaman dilakukan di luar ruangan mulai pukul 08.00 WIB dengan kondisi terlindung dari sinar matahari langsung untuk menghindari merunduknya daundaun tanaman yang berumur muda sehingga 
kanopi tanaman dapat terekam secara optimal. Pencahayaan tambahan diberikan untuk mengantisipasi rendahnya cahaya alami (sinar matahari) yang sampai ke permukaan daun tanaman.

Merujuk pada metode penelitian Beisel et al. (2018) yang telah dimodifikasi, sumber cahaya tambahan yang digunakan ialah masing-masing 2 buah tipe lampu LED putih 10 watt $(6500 \mathrm{~K})$ dan lampu LED full spectrum 18 watt (18 buah red color $=660$ $\mathrm{nm}, 3$ buah blue color $=445 \mathrm{~nm}$, serta masingmasing 1 buah untuk white color $=6000 \mathrm{~K}$, warm white color $=3000 \mathrm{~K}$, infrared color $=750 \mathrm{~nm}$, dan ultraviolet color $=395 \mathrm{~nm}$ ).

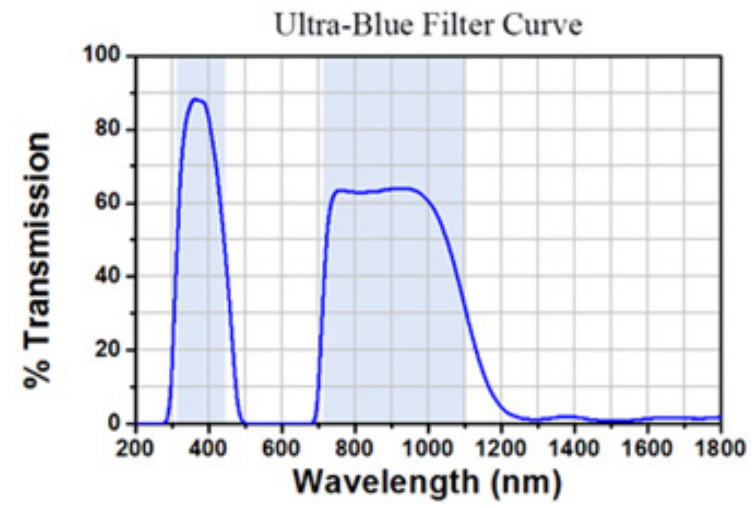

Gambar 1 Panjang gelombang cahaya yang ditransmisikan oleh filter ke lensa kamera. (https://www.spencerscamera.com/store/ graphics/product_graphics/Product_222PI4.jpg)
Kedua lampu LED putih diletakkan di sisi kiri dan kanan tanaman, sedangkan lampu LED full spectrum diletakkan tegak lurus di atas kanopi tanaman. Kamera diletakkan pada tripod (ketinggian $\pm 110 \mathrm{~cm}$ ) di antara kedua lampu led full spectrum, dengan posisi lensa tegak lurus terhadap permukaan kanopi tanaman (Gambar 2).

Sebelum perekaman citra, semua tanaman diletakkan di tempat perekaman dengan kondisi lingkungan sekitar yang relatif sama selama \pm 30-40 menit (Zhu et al. 2018) dan diupayakan tidak terdapat tetesan air pada permukaan atas daun. Perekaman citra berakhir saat gejala awal mosaik terlihat secara kasat mata.

\section{Pengolahan Citra}

Sebelum data citra dikonversi ke SINDVI, area latar belakang tanaman pada citra hasil perekaman dihapus menggunakan eraser tool pada aplikasi GIMP versi 2.8 hingga menyisakan area daun tanaman saja. Konversi data citra dilakukan menggunakan plugin Photo Monitoring (Horning 2012) pada aplikasi Fiji-ImageJ (Gambar 3) dan dihitung menggunakan rumus (Beisel et al. 2018):

$$
\text { SI-NDVI }=\frac{\text { Reflektansi }_{\text {NIR }}-\text { Reflektansi }_{\text {Biru }}}{\text { Reflektansi }_{\text {NIR }}+\text { Reflektansi }_{\text {Biru }}}
$$

Nilai NDVI dari setiap piksel citra daun tanaman diekstrak menggunakan plugin

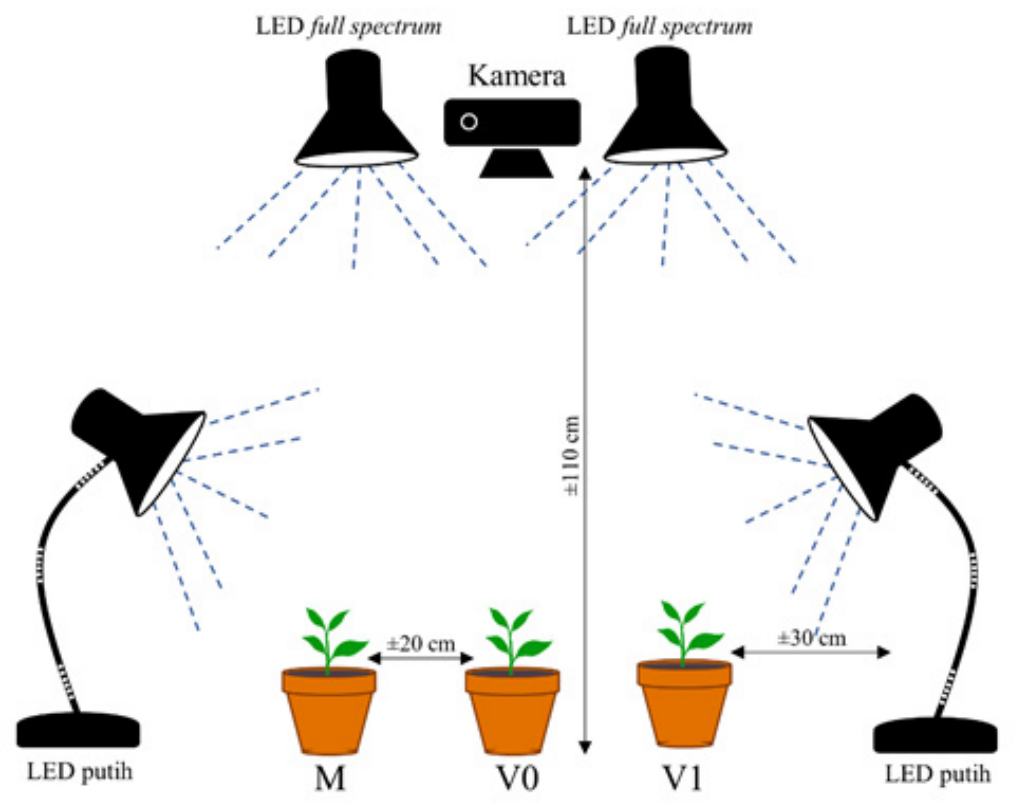

Gambar 2 Skema penempatan cahaya buatan dan posisi kamera saat perekaman citra tanaman. 


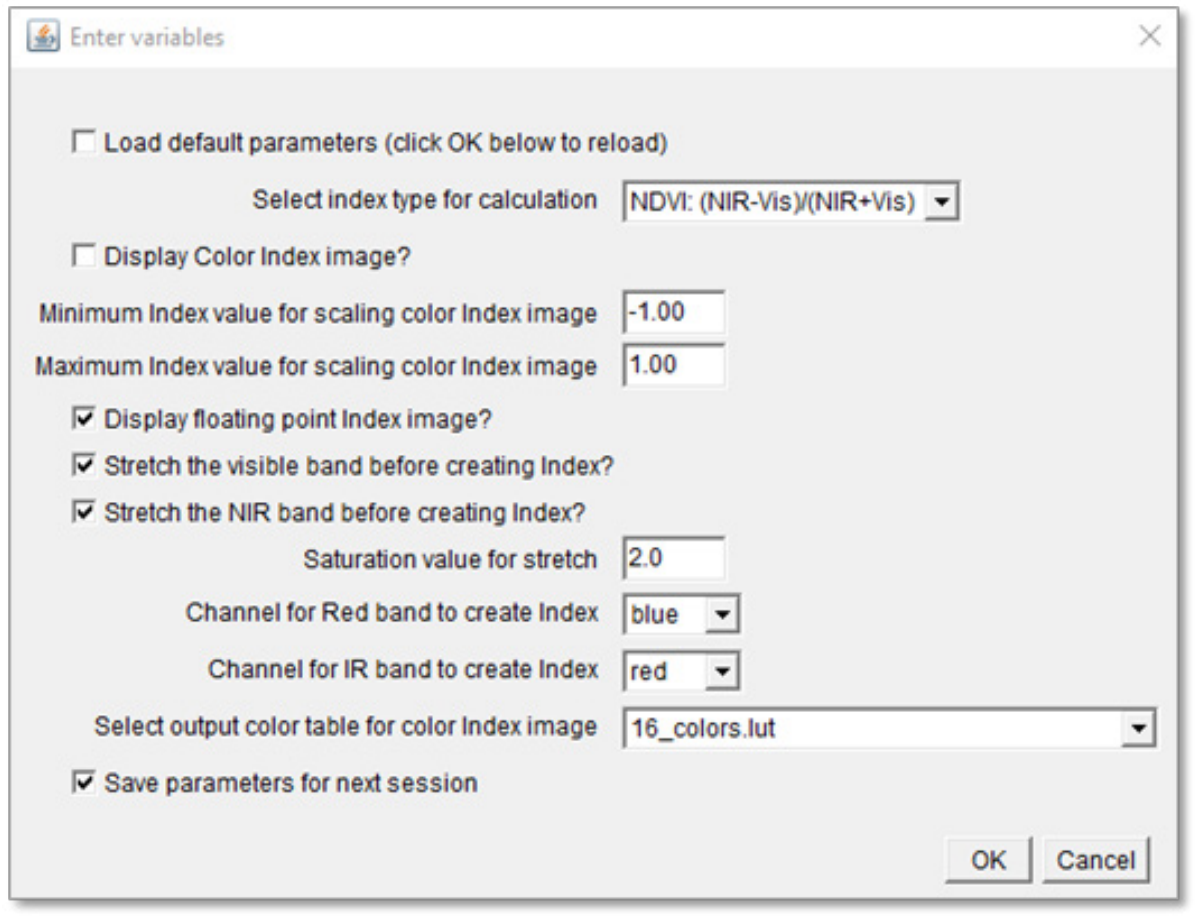

Gambar 3 Pengaturan plugin Photo Monitoiring pada aplikasi Fiji-ImageJ.

Histogram pada aplikasi Fiji-ImageJ dan diekspor ke Microsoft Excel untuk menghitung nilai NDVI terintegrasi menggunakan rumus sebagai berikut:

NDVI terintegrasi $=$ Nilai NDVI $\times$ Jumlah piksel

Nilai NDVI yang digunakan dalam perhitungan ialah $>0.00$ dengan asumsi bahwa jaringan tanaman memiliki nilai NDVI $>0.00$ (Beisel et al. 2018). Citra false-color ditampilkan untuk memetakan area daun yang memiliki nilai NDVI terendah sampai tertinggi yang dibuat menggunakan aplikasi QGIS 3.16.

\section{Analisis Statistik}

Perubahan nilai NDVI terintegrasi pada ketiga perlakuan seiring waktu perekaman dianalisis menggunakan regresi linear sederhana, sedangkan perbedaan rata-rata antarperlakuan dianalisis menggunakan independent sample t-test dengan bantuan aplikasi Microsoft Office Excel 2019.

Kemampuan SI-NDVI sebagai metode deteksi dini gejala virus diestimasi dengan pendekatan algoritma Nä̈ve Bayes Classifier (NBC) menggunakan aplikasi WEKA(Waikato Environment for Knowledge Analysis) versi 3.9.4 (Frank et al. 2016). Setelah diperoleh data NDVI terintegrasi dari masing-masing citra tanaman yang diinokulasi (V1) dan tidak diinokulasi (V0 dan M), selanjutnya data tersebut diklasifikasikan secara manual ke dalam kelas positif untuk V1 dan negatif untuk V0 dan M.

Hasil estimasi menggunakan aplikasi WEKA adalah tabel confusion matrix yang terdiri atas 4 parameter, yaitu: a) true positives (TP) merupakan jumlah data NDVI terintegrasi citra tanaman terinfeksi virus dan terklasifikasi positif oleh algoritma, b) true negatives (TN) merupakan jumlah data NDVI terintegrasi citra tanaman bebas virus dan terklasifikasi negatif oleh algoritma, c) false negatives (FN) merupakan jumlah data NDVI terintegrasi citra tanaman terinfeksi virus yang terklasifikasi negatif oleh algoritma, dan d) false positives (FP) merupakan jumlah data NDVI terintegrasi citra tanaman bebas virus yang terklasifikasi positif oleh algoritma.

Berdasarkan metode penelitian sebelumnya (Petrellis 2019), empat parameter tersebut digunakan untuk mengevaluasi sensitivitas, spesifisitas dan akurasi hasil klasifikasi data NDVI terintegrasi citra tanaman yang diperoleh melalui metode SINDVI. Sensitivitas mengukur jumlah data NDVI terintegrasi citra tanaman terinfeksi 
virus yang terdeteksi secara tepat. Spesifisitas mengukur jumlah data NDVI terintegrasi citra tanaman bebas virus yang terdeteksi secara tepat, sedangkan akurasi menunjukkan frekuensi kedua kategori tersebut berhasil teridentifikasi dengan tepat. Secara matematis, dapat dinyatakan sebagai berikut:

$$
\begin{gathered}
\text { Sensitivitas }=\frac{\mathrm{TP}}{\mathrm{TP}+\mathrm{FN}} \\
\text { Spesifisitas }=\frac{\mathrm{TN}}{\mathrm{TN}+\mathrm{FP}} \\
\text { Akurasi }=\frac{\mathrm{TP}+\mathrm{TN}}{\mathrm{TP}+\mathrm{TN}+\mathrm{FN}+\mathrm{FP}}
\end{gathered}
$$

\section{HASIL}

Hasil pengamatan menunjukkan gejala mosaik mulai terlihat secara kasat mata pada tanaman cabai yang diinokulasi virus TMV pada 18 HSI. Semakin berkembang gejala mosaik, nilai NDVI terintegrasi pada tanaman yang diinokulasi meningkat secara tidak nyata dibandingkan dengan tanaman yang tidak diinokulasi dan minim hara (Gambar 4).

Laju peningkatan nilai NDVI terintegrasi pada tanaman yang diinokulasi hanya berkisar 5.032 piksel per hari, sedangkan pada tanaman yang tidak diinokulasi dan minim hara masing-masing mencapai 21.369 dan 17.063 piksel per hari. Perubahan proporsi nilai NDVI pada area daun selama pengamatan dapat menyebabkan nilai NDVI terintegrasi menjadi bervariasi (Gambar 5).
Hasil uji $\mathrm{t}_{0.05}$ menunjukkan bahwa rata-rata nilai NDVI terintegrasi antara perlakuan V0 dan $\mathrm{M}$ berbeda sangat nyata dengan perlakuan V1, masing-masing pada pengamatan 5 HSI dan 1 HSI (Tabel 1). Secara umum rata-rata nilai NDVI perlakuan V0 lebih rendah pada pengamatan 1-8 HSI dan lebih tinggi pada 1318 HSI dibandingkan dengan V1; sedangkan rata-rata nilai NDVI terintegrasi perlakuan M lebih rendah pada pengamatan 1-13 HSI dan lebih tinggi pada 17-18 HSI dibandingkan dengan V1.

Penggunaan metode SI-NDVI pada deteksi dini gejala mosaik berdasarkan pendekatan NBC menggunakan aplikasi WEKA memiliki sensitivitas, spesifisitas, dan akurasi tertinggi pada pengamatan 5 HSI (Tabel 2). Perlakuan V1 sebagai kelas positif serta V0 dan M sebagai kelas negatif (tidak diinokulasi virus) masing-masing menunjukkan tingkat sensitivitas sebesar $81.8 \%$ dan $90.0 \%$, tingkat spesifisitas sebesar $88.9 \%$ dan $90.0 \%$, serta tingkat akurasi sebesar $85.0 \%$ dan $90.0 \%$.

\section{PEMBAHASAN}

Deteksi dini penyakit tanaman dengan metode non-destruktif akan mengurangi keterlibatan manusia dalam perlindungan tanaman (Golhani et al. 2018), salah satu pendekatannya ialah menggunakan metode SI-NDVI. NDVI merupakan salah satu metode non-desktruktif yang dapat digunakan untuk mendeteksi gejala kerusakan tanaman

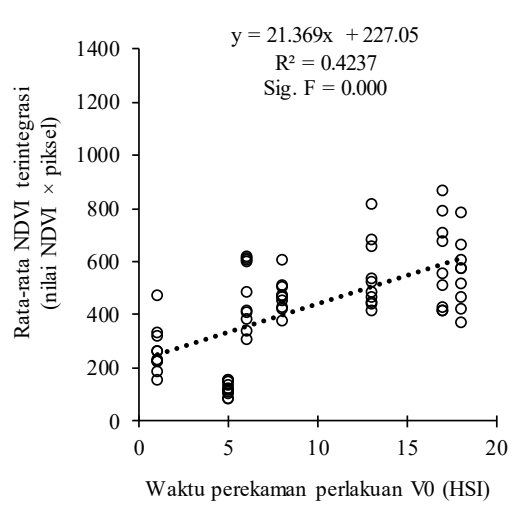

a

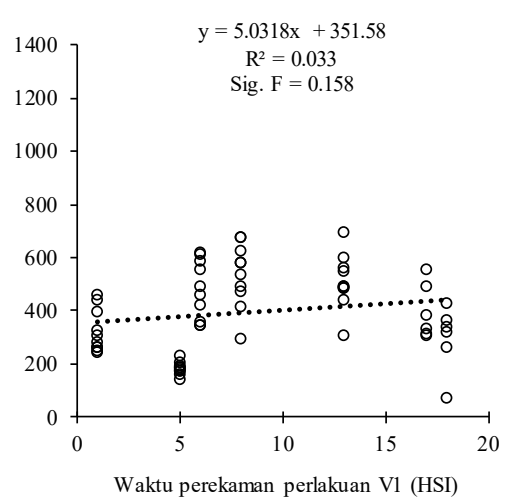

b

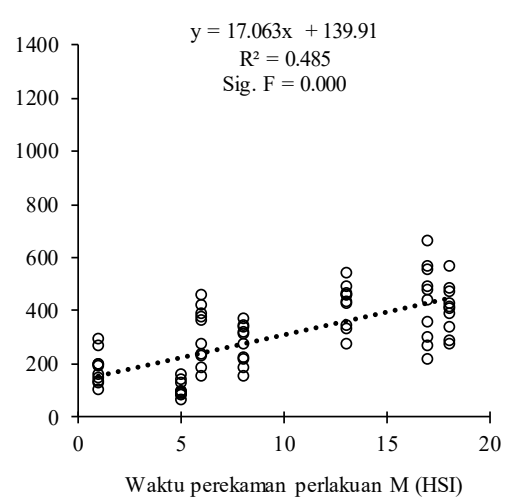

c

Gambar 4 Plot regresi linear waktu perekaman masing-masing perlakuan terhadap rata-rata nilai NDVI terintegrasi (Sig. F $<0.01=$ sangat nyata; Sig. $\mathrm{F} \geq 0.05$ = tidak nyata). a, Tanpa inokulasi; b, Inokulasi virus; dan c, Minim hara. 


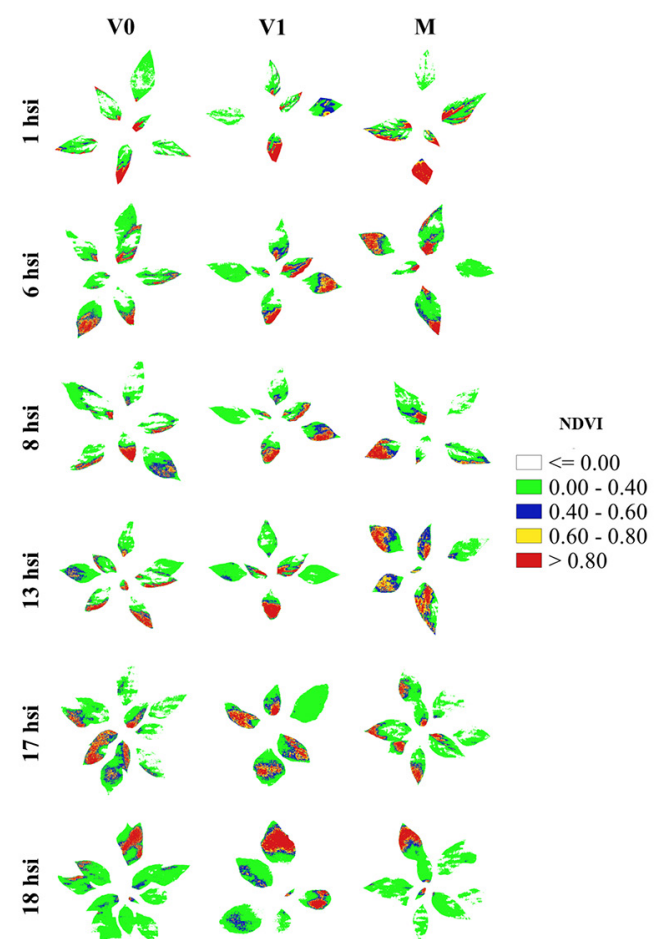

Gambar 5 Citra false-color sampel tanaman yang terinfeksi (V1) dan bebas virus (V0 dan M). akibat cekaman biotik dan abiotik (Sandmann et al. 2018) dengan cara mengukur rasio reflektansi spektral daun tanaman pada panjang gelombang spektrum elektromagnetik cahaya merah (590-670 nm) dan NIR (700-1100 nm) (Yengoh et al. 2015). Berbeda dengan NDVI konvensional, metode SI-NDVI menggunakan rasio reflektansi spektrum biru (400-575 nm) dan NIR (675-775 nm) (Beisel et al. 2018).

Nilai NDVI terintegrasi yang meningkat secara tidak nyata pada daun cabai yang diinokulasiTMVseiring denganperkembangan gejala yang muncul diduga karena sebagian besar daun tanaman yang terinfeksi virus berkurang kemampuannya merefleksikan spektrum NIR dan menyerap spektrum cahaya tampak (biru dan merah). Penurunan kemampuan refleksi dan penyerapan cahaya ini disebabkan oleh kadar klorofil daun yang rendah akibat infeksi virus. Menurut Carter dan Knapp (2001), perbedaan reflektansi

Tabel 1 Rata-rata nilai NDVI terintegrasi dan hasil uji independent sample t-test pada perekaman citra $1-18$ HSI

\begin{tabular}{rllllll}
\hline \multirow{2}{*}{ HSI } & \multicolumn{3}{c}{ Rata-rata NDVI terintegrasi \pm SD } & & \multicolumn{2}{c}{$\Delta$ NDVI terintegrasi } \\
\cline { 2 - 4 } & $\begin{array}{c}\text { Tanpa inokulasi } \\
(\text { V0 })\end{array}$ & $\begin{array}{c}\text { Inokulasi virus } \\
(\mathrm{V} 1)\end{array}$ & $\begin{array}{c}\text { Minim hara } \\
(\mathrm{M})\end{array}$ & & $(\mathrm{V} 0-\mathrm{V} 1)$ & $(\mathrm{M}-\mathrm{V} 1)$ \\
\hline 1 & $267.29 \pm 89.81$ & $323.87 \pm 80.81$ & $183.45 \pm 59.92$ & & -56.57 & $-140.42^{* *}$ \\
5 & $123.15 \pm 26.40$ & $184.45 \pm 24.89$ & $104.84 \pm 28.34$ & & $-61.30^{* *}$ & $-79.61^{* *}$ \\
6 & $477.58 \pm 121.88$ & $479.86 \pm 109.13$ & $310.17 \pm 105.23$ & & -2.29 & $-169.69^{* *}$ \\
8 & $471.49 \pm 62.48$ & $535.28 \pm 120.68$ & $274.86 \pm 74.58$ & & -63.79 & $-260.42^{* *}$ \\
13 & $546.88 \pm 130.45$ & $510.65 \pm 102.03$ & $423.87 \pm 82.15$ & & 36.23 & -86.79 \\
17 & $596.80 \pm 169.91$ & $397.54 \pm 102.77$ & $434.94 \pm 144.99$ & & $199.26^{*}$ & 37.41 \\
18 & $554.12 \pm 126.43$ & $298.08 \pm 123.80$ & $407.50 \pm 90.14$ & & $256.04^{* *}$ & 109.42 \\
\hline
\end{tabular}

Ket: HSI, hari setelah inokulasi; NDVI, normalized difference vegetation index; SD, standar deviasi;

**, sangat nyata; dan *, nyata berdasarkan uji $\mathrm{t}_{0.05}$.

Tabel 2 Sensitivitas, spesifisitas, dan akurasi SI-NDVI sebagai metode deteksi dini gejala virus pada perekaman citra 1-18 HSI

\begin{tabular}{|c|c|c|c|c|c|c|c|}
\hline \multirow[t]{2}{*}{ HSI } & & \multicolumn{2}{|c|}{ Sensitivitas (\%) } & \multicolumn{2}{|c|}{$\begin{array}{l}\text { Spesifisitas (\%) } \\
\text { (Kelas negatif) }\end{array}$} & \multicolumn{2}{|c|}{ Akurasi (\%) } \\
\hline & & V0 & $\mathrm{M}$ & V0 & $\bar{M}$ & V0 & $\bar{M}$ \\
\hline 1 & \multirow{7}{*}{$\begin{array}{c}\mathrm{V} 1 \\
\text { (Kelas positif) }\end{array}$} & 50.0 & 80.0 & 50.0 & 80.0 & 50.0 & 80.0 \\
\hline 5 & & 81.8 & 90.0 & 88.9 & 90.0 & 85.0 & 90.0 \\
\hline 6 & & 25.0 & 77.8 & 12.5 & 72.7 & 20.0 & 75.0 \\
\hline 8 & & 75.0 & 100.0 & 66.7 & 90.9 & 70.0 & 95.0 \\
\hline 13 & & 42.9 & 70.0 & 33.3 & 70.0 & 40.0 & 70.0 \\
\hline 17 & & 62.5 & 0.0 & 85.7 & 60.0 & 73.3 & 56.3 \\
\hline 18 & & 83.3 & 50.0 & 88.9 & 66.7 & 86.7 & 62.5 \\
\hline
\end{tabular}

HSI (hari setelah inokulasi); V0 (Tanpa inokulasi TMV); V1 (Inokulasi TMV); M (Minim hara) 
spektrum cahaya antara tanaman sehat dan tanaman yang mengalami cekaman biotik dan abiotik terjadi pada panjang gelombang $\pm 700 \mathrm{~nm}$ (area spektrum inframerah).

Selisih rata-rata nilai NDVI terintegrasi antara perlakuan V0 dengan V1 yang terlihat sangat nyata pada 5 HSI menunjukkan bahwa metode SI-NDVI dapat dikembangkan sebagai metode deteksi dini infeksi laten virus mosaik. Pada 5 HSI, gejala infeksi virus mosaik tidak terlihat secara kasa mata, sedangkan deteksi menggunakan NDVI secara kuantitatif sudah mencapai indeks 5. Infeksi laten virus mosaik menunjukkan gejala secara kasat mata pada 18 HSI. Metode tersebut juga dapat membedakan gejala antara tanaman terinfeksi virus dan kekurangan hara. Dengan demikian, deteksi dini menggunakan NDVI memberikan informasi yang lebih cepat segera untuk mengantisipasi adanya serangan virus mosaik pada tanaman cabai.

Single Image-NDVI adalah metode nonkontak dan non-dekstruktif yang tidak akan menganggu pertumbuhan tanaman. Berbeda dengan metode serologi atau molekuler yang mengharuskan tindakan destruktif saat melakukan sampling dan pengujian, sehingga berpeluang meningkatkan insiden penyakit di lapang dan kegagalan pengujian di laboratorium akibat kerusakan sampel saat prosesing. Kelebihan lain penerapan metode SI-NDVI di lapangan ialah data terkait status kesehatan tanaman relatif mudah dan cepat diperoleh, khususnya untuk jumlah sampel yang banyak.

Akurasi metode SI-NDVI sebesar 85\%$90 \%$ dalam mendeteksi gejala mosaik yang tak kasat mata tentu saja tidak dapat dibandingkan dengan akurasi teknik serologi atau molekuler yang mampu mendeteksi infeksi virus pada tanaman secara spesifik. Namun sebagai tindakan preventif di lapangan-terutama di pesemaian-metode ini dianggap berpotensi untuk dimanfaatkan sebagai metode deteksi dini tanaman sakit sebelum dikonfirmasi lebih lanjut dengan teknik serologi atau molekuler. Hal ini diperkuat dengan tingkat sensitivitas metode SI-NDVI mendeteksi gejala mosaik mencapai $81.8 \%-90.0 \%$ dan spesifisitas mendeteksi tanaman bebas virus mencapai $88.9 \%-90.0 \%$.

\section{UCAPAN TERIMA KASIH}

Penulis berterima kasih kepada pihak Kementerian Pendidikan dan Kebudayaan Republik Indonesia atas dukungan biaya yang diberikan melalui program Beasiswa Pendidikan Pascasarjana Dalam Negeri (BPPDN) tahun 2017. Terima kasih juga diucapkan kepada Kementerian Riset dan Teknologi/Badan Riset dan Inovasi Nasional, Deputi Bidang Penguatan Riset dan Pengembangan Republik Indonesia atas pendanaan penelitian yang diberikan berdasarkan skema Penelitian Disertasi Doktor tahun anggaran 2020 (Nomor Kontrak: 1/E1/ KP.PTNBH/2020).

\section{DAFTAR PUSTAKA}

Almeida JEM, Figueira ADR, Duarte P de SG, Lucas MA, Alencar NE. 2018. Procedure for detecting tobamovirus in tomato and pepper seeds decreases the cost analysis. Bragantia. 77(4):590-598. DOI: https:// doi.org/10.1590/1678-4499.2017317.

Beisel NS, Callaham JB, Sng NJ, Taylor DJ, Paul AL, Ferl RJ. 2018. Utilization of single-image normalized difference vegetation index (SI-NDVI) for early plant stress detection. Appl Plant Sci. 6(10): e01186. DOI: https://doi.org/10.1002/ aps3.1186.

Bosse JL, Adhiwibawa MAS, Brotosudarmo THP. 2019. Multispectral imaging with raspberry $\mathrm{Pi}$ for assessment of plant health status. Indones $\mathrm{J}$ Nat Pigment. 1(2):30. DOI: https://doi.org/10.33479/ ijnp.2019.01.2.30.

Carter GA, Knapp AK. 2001. Leaf optical properties in higher plants: linking spectral characteristics to stress and chlorophyll concentration. Am J Bot. 88(4):677-684. DOI: https://doi.org/10.2307/2657068.

Calderón R, Navas-cortés JA, Zarco-tejada PJ. 2015. Early detection and quantification of verticillium wilt in olive using 
hyperspectral and thermal imagery over large areas. Remote Sens. 7:5584-5610. DOI: https://doi.org/10.3390/rs70505584.

Chávez P, Zorogastúa $\mathrm{P}$, Chuquillanqui C, Salazar LF, Mares V, Quiroz R. 2009. Assessing Potato yellow vein virus (PYVV) infection using remotely sensed data. Int $\mathrm{J}$ Pest Manag. 55(3):251-256. DOI: https:// doi.org/10.1080/09670870902862685.

DamiriN, SofitaIS, Effend TA, Rahim SE.2017. Infection of some cayenne pepper varieties (Capsicum frustescens L.) by Tobacco mosaic virus at different growth stages. AIP Conference Proceedings. 1885:1-6. DOI: https://doi.org/10.1063/1.5005942.

Dijkstra J, Jager CP de. 1998. Practical Plant Virology: Protocols and Exercises. Berlin (DE): Springer. DOI: https://doi. org/10.1007/978-3-642-72030-7.

Frank E, Hall MA, Witten IH. 2016. The WEKA Workbench. Online Appendix for Data Mining: Practical Machine Learning Tools and Techniques. https://www. cs.waikato.ac.nz/ml/weka/citing.html.

Golhani K, Balasundram SK, Vadamalai G, Pradhan B. 2018. A review of neural networks in plant disease detection using hyperspectral data. Inf Process Agric. 5(3):354-371. DOI: https://doi. org/10.1016/j.inpa.2018.05.002.

Hornero A, North P, Camino C, Zarco-Tejada $\mathrm{P}$, Boscia D, Calderon R, Navas-Cortes J, Morelli M, Kattenborn T, Susca L, et al. 2018. Previsual symptoms of Xylella fastidiosa infection revealed in spectral plant-trait alterations. Nat Plants. 4(7):432439. DOI: https://doi.org/10.1038/s41477018-0189-7.

Horning. 2012. Public Lab: Update on the photo monitoring plugin for ImageJ/Fiji. [diakses 2019 Agu 26]. https://publiclab. org/notes/nedhorning/11-1-2012/updatephoto-monitoring-plugin-imagejiji.

Jacquemoud S, Ustin SL. 2001. Leaf optical properties: a state of the art. Di dalam: Proc. 8th International Symposium Physical Measurements \& Signatures in Remote Sensing. Aussois (FR): CNES. hlm 223-232.
Krezhova DD, Ts II, Hristova DP, Yanev TK. 2009. Spectral remote sensing measurements for detection of viral infections in tobacco plants (Nicotiana tabacum L .). Fund Space Res. 2009:43-46.

Kshirsagar AV, Deshmukh RR, Janse P V., Gupta R, Kayte JN. 2019. Detection of disease from Chilly plant using vegetation indices. Int J Comput Sci Eng. 7(1):333337. DOI: https://doi.org/10.26438/ijcse/ v7i1.333337.

Kumar S, Prakash HS. 2016. Detection of Tobacco mosaic virus and Tomato mosaic virus in pepper seeds by enzyme linked immunosorbent assay (ELISA). Arch Phytopathol Plant Prot. 49(1-4):59-63. DOI: https://doi.org/10.1080/03235408.2 012.658991.

Kumar S, Udaya Shankar AC, Nayaka SC, Lund OS, Prakash HS. 2011. Detection of Tobacco mosaic virus and Tomato mosaic virus in pepper and tomato by multiplex RT-PCR. Lett Appl Microbiol. 53(3):359363. DOI: https://doi.org/10.1111/j.1472765X.2011.03117.x.

Lowe A, Harrison N, French AP. 2017. Hyperspectral image analysis techniques for the detection and classification of the early onset of plant disease and stress. Plant Methods. 13(80):1-12. DOI: https:// doi.org/10.1186/s13007-017-0233-z.

Mahlein AK. 2016. Plant disease detection by imaging sensors-parallels and specific demands for precision agriculture and plant phenotyping. Plant Dis. 100(2):241251. DOI: https://doi.org/10.1094/PDIS03-15-0340-FE.

Miranda J da R, Alves M de C, Pozza EA, Santos Neto H. 2020. Detection of coffee berry necrosis by digital image processing of landsat 8 oli satellite imagery. Int $\mathrm{J}$ Appl Earth Obs Geoinf. 85:101983. DOI: https://doi.org/10.1016/j.jag.2019.101983.

Oh S, Ashapure A, Marconi TG, Jung J, Landivar J. 2019. UAS based Tomato yellow leaf curl virus (TYLCV) disease detection system. Di dalam: Proceedings of SPIE. 11008:23. DOI: https://doi. org/10.1117/12.2518703. 
Pazarlar S, Gümüs M, Öztekin GB. 2013. The effects of Tobacco mosaic virus infection on growth and physiological parameters in some pepper varieties (Capsicum annuum L.). Not Bot Horti Agrobot ClujNapoca. 41(2):427-433. DOI: https://doi. org/10.15835/nbha4129008.

Petrellis N. 2019. Plant disease diagnosis for smart phone applications with extensible set of diseases. Appl Sci. 9(1952):1-22. DOI: https://doi.org/10.3390/app9091952.

Sandmann M, Grosch R, Graefe J. 2018. Use of features from fluorescence, thermography, and NDVI imaging to detect biotic stress in lettuce. Plant Dis. 102(6):1101-1107. DOI: https://doi.org/10.1094/PDIS-10-171536-RE.

Sankaran S, Maja JM, Buchanon S, Ehsani R. 2013. Huanglongbing (citrus greening) detection using visible, near infrared and thermal imaging techniques. Sensors. 13:2117-2130. DOI: https://doi. org/10.3390/s130202117.

Tattaris M, Reynolds MP, Chapman SC. 2016. A direct comparison of remote sensing approaches for high-throughput phenotyping in plant breeding. Front Plant Sci. 7:1-9. DOI: https://doi.org/10.3389/ fpls.2016.01131.

Tucker CJ. 1979. Red and photographic infrared linear combinations for monitoring vegetation. Remote Sens Environ. 8:127150. DOI: https://doi.org/10.1016/00344257(79)90013-0.

Vanella D, Consoli S, Ramírez-Cuesta JM, Tessitori M. 2020. Suitability of the MODIS-NDVI time-series for a posteriori evaluation of the Citrus tristeza virus epidemic. Remote Sens. 12(12). DOI: https://doi.org/10.3390/rs12121965.

Yengoh GT, Dent D, Olsson L, Tengberg AE. 2015. Use of the Normalized Index (NDVI) to Assess Diff erence Vegetation Current Status, Future Multiple Scales. Swissterland $(\mathrm{CH})$ :Springer.

Zhu W, Chen H, Ciechanowska I, Spaner D. 2018. Application of infrared thermal imaging for the rapid diagnosis of crop disease. IFAC Pap. 51(17):424430. DOI: https://doi.org/10.1016/j. ifacol.2018.08.184. 